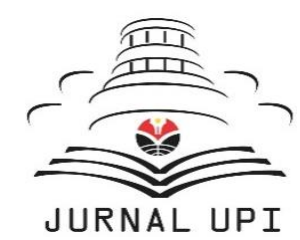

INDONESIAN JOURNAL OF APPLIED LINGUISTICS

Vol. 10 No. 1, May 2020, pp. 271-282

Available online at:

https://ejournal.upi.edu/index.php/IJAL/article/view/25069

https://doi.org/10.17509/ijal.v10i1.25069

\title{
The use of metadiscourse in academic writing by Malaysian first-year ESL doctoral students
}

\author{
Lo Yueh Yea*, Juliana Othman, and Lim Jia Wei \\ Department of Language and Literacy Education, Faculty of Education, University of Malaya, \\ Jalan Universiti, 50603, Kuala Lumpur, Malaysia.
}

\begin{tabular}{|c|c|}
\hline $\begin{array}{l}\text { ABSTRACT } \\
\text { Metadiscourse refers to linguistic items, which functions } \\
\text { readers of a text (Hyland, 2004). The use of metadiscours } \\
\text { contexts, yet, little works are focusing on disciplinary m } \\
\text { To address this gap, this study explored, described, } \\
\text { metadiscourse by eight Malaysian first-year ESL doctor } \\
\text { education. The study reported in this article focuses on } \\
\text { time. This study is quantitative in nature with a corpus-b } \\
\text { to examine the frequency of three dimensions of acade } \\
\text { textual, engagement, and evaluative The results of this } \\
\text { dimension (3.1\%) was the lowest of all three dimen } \\
\text { argument that first-year ESL doctoral students are less ex } \\
\text { resources, and (ii) frequency of all three dimensions of ac } \\
\text { across time between first written drafts to the final w } \\
\text { doctoral students, who are writing in different fields of } \\
\text { that teaching and learning of disciplinary metadiscours } \\
\text { demonstration, and practice of its use, and development } \\
\text { Keywords: Academic writing; corpus analysis; ESL do }\end{array}$ & $\begin{array}{l}\text { h a connection with imagined } \\
\text { ved much attention in various } \\
\text { rse, that has been carried out. } \\
\text { ared the use of disciplinary } \\
\text { across four areas of study in } \\
\text { nt or changes in writing over } \\
\text { ach utilizing AntConc (3.4.4) } \\
\text { urse in their writing, namely } \\
\text { how that (i) the engagement } \\
\text { vritten work, reinforcing the } \\
\text { at using textual metadiscourse } \\
\text { scourse in their writing differs } \\
\text { ts. These are first-year ESL } \\
1 \text { research. The implication is } \\
\text { involve explicit explanation, } \\
\text { lemic writing process. } \\
\text { ents; metadiscourse }\end{array}$ \\
\hline $\begin{array}{l}\text { First Received: } \\
27 \text { November } 2019 \\
\text { Final Proof Received: } \\
28 \text { May } 2020 \\
\end{array}$ & $\begin{array}{c}\text { Accepted: } \\
\text { 20 April 2020 } \\
\text { Published: } \\
\text { 31 May 2020 } \\
\end{array}$ \\
\hline \multicolumn{2}{|c|}{$\begin{array}{l}\text { How to cite (in APA style): } \\
\text { Lo, Y. Y., Othman, J., \& Lim, J. W. (2020). The use of metadiscourse in academic writing by } \\
\text { Malaysian first-year ESL doctoral students. Indonesian Journal of Applied Linguistics, } \\
\text { 10(1), 271-282. https://doi.org/10.17509/ijal.v10i1.25069 }\end{array}$} \\
\hline
\end{tabular}

\section{INTRODUCTION}

Academic writing is often seen as the underlying problem in higher education especially for first-year ESL doctoral students, regardless of the major, in the field of studies (Aitchison \& Lee, 2006; Kamler \& Thomson, 2014). As this may contribute to tensions and challenges doctoral students encounter due to uncertainty that, whether their practices aligned with those of the discipline (Bieber \& Worley, 2006; Hyland, 2012; Park, 2013), a new note of urgency, which calls for research on strategic manipulation of interpersonal and rhetorical elements in academic writing (Ho \& Li, 2018; Hyland, 2014; Hyland \& Jiang, 2018). In response to this, some researchers and teachers of academic writing in academic contexts have focused on researching textual, engagement, and evaluative dimensions of academic discourse. As reviewed by Kuhi and Behnam (2011), many of these studies 'can be clustered under the uniting umbrella of metadiscourse' (p.98). Metadiscourse refers to linguistic items that function to establish a connection with imagined readers of a text (Hyland, 2004).

Metadiscourse was first introduced by Harris (1959) in applied linguistics, which later evolved through the work of Vande Kopple's (1985) as 'discourse about discourse', Crismore's (1989) as 'discoursing about the discourse' and Williams'

\footnotetext{
* Corresponding Author

Email:pva170080@siswa.um.edu.my
} 
(1981) as 'writing about writing'. While several researchers (Crismore \& Farnsworth, 1990; Hyland, 2004, 2005; Swales, 1990) have acknowledged the vagueness of the concept as metadiscourse lacks theorization, clear definitions, and functions, Halliday (1994) suggested that language should fulfill three functions namely: ideational, textual and interpersonal. This suggestion builds on the connection of metadiscourse to the work of others scholars, such as, Jakobson's (1980) metalinguistic function, Hyland's (2004) self-reflective linguistic expression, Hyland, and Hyland and Tse's (2004) interactive and interactional resources, and Hyland's (2017) idea, where 'language does not only refers to the world, concerned with exchanging information of various kinds but also itself: with material which helps readers to organize, interpret and evaluate what is being said' (p.17). This idea embraces metadiscourse functions. In other words, metadiscourse has textual functions, that help writers to negotiate the meaning and 'engage with readers as members of a particular community’ (Hyland, 2005, pp.37)

As Hyland (2005) argues, writing involves meaning-making. Thus, academic writing done with limited awareness and knowledge of textual and rhetorical elements becomes problematic. This is seen as a sign of deficit, that disrupts the flow of argument, intention, and voice in writing, while also affecting a writer's choice of words. These may accumulate to the issues of doctoral students' withdrawal and complications in completing their doctorate studies (Jones, 2011; Kamler \& Thomson, 2014). In an ESL learning context, first-year doctoral students are newcomers in their selected field of studies and face more challenges in the L2 academic writing process because they are required to write in a second language, in which many of them may not be fully proficient (Matsuda et al., 2013). Yet, general academic writing classes and courses still emphasize the teaching of L2 written structure, than on developing writers' awareness in using textual, engagement, and evaluative dimensions of academic discourse in an academic context (Cimasko \& Reichelt, 2011; Juliaty, 2019). The concepts of textual, engagement and the evaluative dimension of academic discourse will be explained in the metadiscourse section below. The lack of awareness is an issue in the teaching and learning of academic writing and English for Specific Purposes (ESP) in university where the importance of disciplinary writing and rhetorical elements is fundamental for effective communication in academic writing (Bhatia, 2014; Coffin et al., 2005; Evans \& Green, 2007; Hyland, 1999, 2014; Hyland \& Jiang, 2018; Hyland \& Tse, 2004).

The literature on academic writing acknowledges that the concept of metadiscourse brings to the fore structure of understanding academic discourse in writing (Crismore, 1983;
Hyland, 1998, 2002, 2005, 2008, 2011, 2014, 2015; Lautamatti, 1987; Matsuda \& Tardy, 2007; Vande Kopple, 1985). Several cross-cultural studies (Adel, 2006; Breivega et al., 2002; Vold, 2006), have shown that metadiscourse is not uniform across languages and is dependent on the way texts are written (Harwood, 2005; Hewings \& Hewings, 2001). Additionally, previous studies that have adopted communicative purposes in genre-based studies of metadiscourse (Swales, 1990, 2004), have suggested that different genres and audiences may influence the use of metadiscourse. While there is a body of literature on different academic genres involving L1 and L2 writers, there are little empirical studies, focused on emergent academic writers' on-going and unpublished written works (Dobakhti \& Hassan, 2017; Hyland, 2015).

This study focuses on disciplinary metadiscourse, as framed by the use of textual, engagement, and evaluative dimensions of academic discourse, used by emerging academic writers over time. Hence, the focus is on the first-year ESL doctoral students' drafts of research proposals instead of edited works that have been published (e.g., research articles, books, textbooks) or completed (e.g., master and Ph.D. dissertations). This is due to the assumption that aspiring first-year ESL doctoral students' on-going works, may offer insight on how the use of textual, engagement, and evaluative dimensions of academic discourse varies across time. This usually is between the first written draft to the final written draft, and between first-year ESL doctoral students, who work in different fields of education research. This article aims to offer insights into the way first-year ESL doctoral students organize texts. In doing so, this study highlights the importance of practicing disciplinary textual, engagement, and evaluative dimensions of academic discourse. Besides, this study invites discussion regarding the teaching of academic writing and ESP in institutes of higher education. The research question guided this study is: What are the similarities and differences of textual, engagement, and evaluative dimensions of academic discourse in writing used by first-year ESL doctoral students during their first year of doctoral studies?

\section{Metadiscourse}

Following the perspective of functional metadiscourse (Hyland, 2000; 2004; 2017), this study draws on Hyland's conceptions of metadiscourse, which is defined as textual communication within an academic community. Functional metadiscourse refers to linguistic resources, that enable writers to use language with credibility in a given context (Hyland, 2000). To write with credibility and to use various features of language in an academic context, demands familiarity with readers and is played out through writers' choice of language, with strategic employment of linguistic resources (Hyland, 2015, 
2017; Hyland \& Tse, 2004). Functional metadiscourse thus captures the basic principle of communication by emphasizing interactivity among ideational, interpersonal, and textual meaning (Hyland, 2005). Ideational refers to the writers' voice while interacting with others and interpersonal refers to the way writers interact with readers in the expression of relationships and values. These two principles reflect the fundamental aspect of human interaction between writers and readers. The activity of writing in an academic context relates to the ways writers organize the messages that make sense to themselves as writers and to readers of the texts. These ideational, interpersonal, and textual meanings were part of Hyland's (2000) metadiscourse model, which are especially significant to help writers make a connection with the imagined readers of a text.

Hyland's model of metadiscourse originally consists of two dimensions: textual dimension which refers to the organization of texts, while interpersonal dimension reflects the writer-reader relations. In the light of recognizing the interpersonal dimension, Hyland (2005) has put forth a view, claiming that, all metadiscourse categories are interpersonal, he proposed a change in terminology and adopted Thompson's (2001) interactive dimension (instead of textual dimension) and interactional dimension (instead of interpersonal dimension). Due to this, Hyland's (2004) model of metadiscourse consists of interactive and interactional dimensions. These two dimensions in Hyland's (2004) model by its suggestion refers to interaction. In the metadiscourse model, engagement markers categories (e.g., writeroriented, reader-oriented, writer-reader oriented) are placed under the interactional dimension. However, in the modified model of metadiscourse used in this study, the textual dimension is adopted from Hyland's (2000) model of metadiscourse and the interactional dimension is further divided into two dimensions: engagement and evaluative. The textual dimension that was used in this study refers to the writer's effort to create his or her preferred interpretations. The reason for keeping Hyland's (2000) terminology, textual dimension instead of interactive dimension is because the current study focuses on first-year ESL doctoral students' development or changes of writing over time. This is usually happening between first written drafts to the final written drafts during their first year of doctoral studies. At the moment, readers' involvement is limited because these drafts focus on the participants' expression, as writers and their acts of drafting often involve their self-conceptions and perceptions. In contrast, research work on dissertation or journal articles are different, because they are meant for a group of readerships, which involve a certain degree of interaction between the writer and the reader. Furthermore, this study aims to explore, if these participants develop their writers' identity overtime.
The engagement dimension used in this study had been proposed in Hyland's model of metadiscourse. In his metadiscourse model, the author integrated engagement markers categories under the interactional dimensions. However, in the modified model of metadiscourse, that was used in this study, makes the interactional dimension be further divided into two different dimensions: engagement and evaluative. These two dimensions in Hyland's (2004) model, by its suggestion, refers to the writers' efforts to anticipate readers' knowledge and 'involve readers in the argument by alerting them to the authors' perspective towards both propositional information and readers themselves' (p.168). However, the engagement dimension that is used in this study refers to writers' engagement with self as writers. The decision to continue using the engagement dimension is proposed by Hyland, but the reason it was modified as a single dimension is that the participants' experiences in drafting their doctoral research proposals are bound up with their dynamic self-perceptions.

The evaluative dimension that is used in this study provides a direct association from the verb 'to evaluate' and the decision to adopt the term is based on the following views by Thompson (2001) and Hyland (2004). As noted by Thompson (2001), interactional involve assessment of the content, through evaluation by writer and reader while Hyland (2004)'s interactional dimension draws on evaluative features. For example, attitude markers (writers' attitude); hedges (writers' reluctance), and boosters (writers' certainty). Although, the present study adopted the term, evaluative, evaluative dimension that is used in this study, refers to writers' effort to go through the process of self-assessment (e.g., evaluate their writing by looking at other writers in his or her chosen field). This dimension thus relates to how writers position themselves, by looking at other writers' work of similar discipline.

This means the modified version for the current study includes three dimensions of academic discourse. These three dimensions are (1) textual, (2) engagement, and (3) evaluative. First, the textual dimension consists of five categories of resources namely transitions (e.g., and), evidential (e.g., according to), code glosses (e.g., such as), frame markers (e.g., first) and endophytic (e.g., namely). Transitions include mainly conjunctions, which are used to link words, while frame markers refer to text boundaries like sequences and stages. Endophorics refer to information from other texts, that facilitates readers' comprehension, through reference to other materials (Hyland, 1998). This resource thus relates to evidential that, concerned with source reference from other texts and code glosses that helps readers to grasp the ideational information in other ways. Second, the engagement dimension consists of three categories of resources namely: writer-oriented markers (e.g., I, we), reader-oriented markers (e.g., 
you), and writer-reader oriented markers (e.g., us, our). The engagement dimension is used to make explicit reference to either the writers or readers and to explicitly refer to the relationship that the writer attempts to build with the readers in the text. Third, the evaluative dimension consists of three categories of resources namely hedges (e.g., might, perhaps), boosters (e.g., in fact, definitely) and attitude markers (e.g., I agree). Hedges withhold writer's full commitment to propositional information; boosters imply writers' certainty of the propositional information, and attitude markers imply the writers' attitude towards propositions. Table 1 below presents the metadiscourse model.

Table 1

The Metadiscourse Model

\begin{tabular}{|c|c|c|}
\hline Column 1 & Column 2 & Column 3 \\
\hline $\begin{array}{l}\text { Hyland's (2000) model of } \\
\text { metadiscourse }\end{array}$ & $\begin{array}{l}\text { Hyland's (2004) model of } \\
\text { metadiscourse }\end{array}$ & $\begin{array}{l}\text { The modified version for the current } \\
\text { study }\end{array}$ \\
\hline Textual & Interactive & Textual \\
\hline 1. Transitions & 1. Transitions & 1. Transitions \\
\hline 2. Evidentials & 2. Evidentials & 2. Evidentials \\
\hline 3. Code glosses & 3. Code glosses & 3. Code glosses \\
\hline 4. Frame markers & 4. Frame markers & 4. Frame markers \\
\hline \multirow[t]{2}{*}{ 5. Endophorics } & 5. Endophorics & 5. Endophorics \\
\hline & & Engagement \\
\hline Interpersonal & Interactional & 1. Writer-oriented markers \\
\hline 1. Self mentions & 1. Self mentions & 2. Reader-oriented markers \\
\hline 2. Engagement markers & 2. Engagement markers & 3. Writer-reader oriented markers \\
\hline 3. Hedges & 3. Hedges & \\
\hline 4. Boosters & 4. Boosters & Evaluative \\
\hline \multirow[t]{3}{*}{ 5. Attitude markers } & 5. Attitude markers & 1. Hedges \\
\hline & & 2. Boosters \\
\hline & & 3. Attitude markers \\
\hline
\end{tabular}

Note: Modified from Hyland's model of metadiscourse

\section{METHOD}

\section{The study}

This study concerns the first-year ESL doctoral students' academic written communication in academic writing. The target participants were all first-year ESL doctoral students from a leading institution in Malaysia. All participants were at the stage of preparing a full research proposal as part of their doctoral studies, during the two-semester conditional enrolment period. Nevertheless, the participants' age and background experiences were not sought to be a determinant for selection. Data was collected from the participants who had registered in 2019 across four areas of study in the field of education at an established Malaysian institution. These participants were involved in all the four areas of study in the education field, which are: (i) curriculum and instructional technology (CIT), (ii) educational management, planning and policy (EMPP), (iii) educational psychology and counseling (EPC), and (iv) language and literacy education (LALE). All written drafts of their research proposals, encompassing the introduction, literature review, and methodology chapters were collected as data.

\section{Corpus}

The corpus analyzed in this study encompass 43 drafts of research proposals, which total 64,500 words altogether. Each participant provided about six to seven drafts of the research proposal, during the conditional enrolment period of one year. The reason for collecting these first-year ESL doctoral students' written drafts of their research proposals, during their first year of doctoral studies was to explore the ways emergent academic writers use metadiscourse to organize texts. These written drafts were not edited or completed works that have been published. This means that these written drafts are the products produced in different stages of the writing process and includes a change element, to how the use of textual, engagement and evaluative dimensions of academic discourse in writing varies across time between first written drafts to the final written drafts, and between first-year ESL doctoral students who engage in different fields of education research.

\section{Data analysis}

A quantitative design with a corpus-based approach comprising general distribution, density, and frequency counts was employed. By doing so, it highlights the ways first-year ESL doctoral students who are writing in different areas of educational research use metadiscourse, for example, identifying and comparing the variations of metadiscourse used across time, and noting signs of change in the three dimensions of academic discourse (textual, engagement and evaluative) in writing. In examining the frequency of textual, engagement and evaluative dimensions of academic discourse, AntConc Build 3.4.3 software developed by Anthony (2014) was used. All drafts were analyzed by looking at all items 
in the context. This process consisted of repeatedly reading each draft until all relevant textual, engagement, and evaluative items were categorized. Once all the items had been categorized, the distribution, occurrences, and density of each dimension were calculated. Each item was then reexamined carefully, in its original contexts. Finally, a final figure was calculated in proportion per 1,000 words, to facilitate comparison among the drafts of research proposal across four areas of study in the field of education.

\section{RESULTS}

This study provides insights into the ways first-year ESL doctoral students use disciplinary metadiscourse to engage in their field of research and an exploration into the ways they organize texts across time between first written drafts to final written drafts. The results of the calculation are presented in Tables 2, 3, 4, 5, and 6 . The first section would present the overall frequency of textual, engagement, and evaluative dimensions, followed by a detailed tabulation of findings for each of the four areas of study in education.

Overall frequency of textual, engagement and evaluative dimensions

Table 2 presents the overall frequency for the three dimensions of academic discourse.

Table 2

Frequency Dimensions of Academic Discourse from 43 Drafts of Research Proposal

\begin{tabular}{lllcc}
\hline No. & Dimensions of academic discourse & Category & Frequency & Total frequency \\
\hline 1. & Textual & Transition & 908 & 4325 \\
& & Evidentials & 2326 & \\
& & Code glosses & 335 & \\
& & Frame markers & 334 & \\
$2 . \quad$ Engagement & Endophorics & 422 & 156 \\
& & Writer-oriented & 80 & \\
3. & \multirow{2}{*}{ Evaluative } & Reader-oriented & 47 & 571 \\
& & Writer-reader oriented & 29 & \\
\hline
\end{tabular}

Overall, the highest total frequency was the textual dimension $(4325 / 85.6 \%)$ followed by the evaluative dimension $(571 / 11.3 \%)$, while that of the engagement dimension was third $(156 / 3.1 \%)$ (see Table 2). The strong use of textual dimension may reflect that first-year ESL doctoral students wanted to negotiate the academic language and literacy demands in an ESL context. This is because they are required to write in a second language or they were likely to present their increased level of certainty as these textual dimensions were commonly used in scholarly academic writing (Hyland, 2004). In the textual dimension, it was also evident from the frequency counts that the evidential category was the highest compared to other categories. This is far more use of evidential, by first-year ESL doctoral students, and it may indicate the importance of citation in academic writing, as it helps to justify an argument and demonstrates the writers' position (Hyland, 2004).

In contrast, the findings showed that the engagement dimension (3.1\%) was the lowest of all three dimensions. This $3.1 \%$ indicates the rare occurrence of this engagement dimension in firstyear ESL doctoral students' research proposal writing. The participants of the present study showed a considerably low use for engagement dimension than writers of other studies (Hyland \& Tse, 2004; Kuhi \& Behnam, 2011). These participants used only
$3.1 \%$, which was less than first-year ethnic Chinese university students from different faculties and schools in Ho and Li (2018)'s study, the first-year L1 and L2 undergraduate students in Lee and Deakin (2016), the final-year L1 Mandarin undergraduates in Li and Wharton (2012). These past studies also found low use of engagement dimensions in the students' academic writing. However, the difference between these past studies and the current study is that they involved different groups of writers: undergraduates and first-year doctoral students.

There is another important point to consider as low-level usage of engagement dimension may also indícate that first-year ESL doctoral students were less experienced in promoting their voice as academic writers. This is also plausible as first-year ESL doctoral students, do not have a clear disciplinary understanding of their areas of studies yet and as a result, they may face equal or more difficulties to write their doctoral research proposals. In simple terms, when students are uncertain about their disciplinary knowledge, they may attempt to present themselves as credible writers by using more evidential in their writing. They become more dependent and concerned about the event of citation instead of critically present an argument in their doctoral research proposal writing. Thus, this may indicate that first-year ESL doctoral students were most likely unable to explore an issue as the writer 
with their reader 'as an equal, a conversationalist partner' (Kuhi \& Behnam, 2011, pp.103).

As shown in Tables 3, 4, 5, and 6 below, the first-year ESL doctoral students used far more textual dimension, than engagement and the evaluative dimensions of academic discourse in their research proposal writing. Specifically, the evidential $(46 \%)$ and transition (18\%) categories were the most frequent metadiscourse resources used. This use of evidential provides some support for several researchers' (Hyland, 2004; Hyland \& Tse, 2004; Kuhi \& Behnam, 2011) arguments that doctoral students are more invested in establishing their academic credentials in academic writing (Hyland \& Tse, 2004; Kuhi \& Behnam, 2011), and in constructing a 'skilled writer identity' (Hyland, 2004, pp.142). In other words, evidential could contribute to the understanding of an argument by helping readers to distinguish who is responsible for a position in the argument. These findings lend support to previous studies by Kuhi and Behnam (2011), where their study reported the high usage of evidential and transitions, but in a different type of corpus. The high frequency of evidential was found in the handbook, while the transition was in a scholarly textbook chapter. As highlighted by Kuhi and Behnam (2011), this high usage for both evidential and transition reflected two unique qualities in terms of the target audience and institutional roles. These two qualities will be discussed in the discussion section below.

\section{DISCUSSION}

The overall frequency of textual, engagement, and evaluative dimensions from the findings suggest that textual dimension are highly regular phenomena in terms of metadiscourse resources. It had been found that the textual dimension $(85.6 \%)$ of academic discourse employed in writing was more than the other two dimensions of academic discourse: engagement $(11.3 \%)$ and evaluative $(3.1 \%)$ across four areas of study in education. These findings can perhaps, partly be explained by the fact doctoral research proposal writing, regardless of studying major is concerned with texts organization. This text organization owes a great deal to writers' clear conception of negotiating meaning in academic writing (Hyland, 2000, 2005). In other words, if this process of negotiation for meaning is done with limited knowledge of textual metadiscourse resources, it might affect writers' flow of argument, intention, and voice in writing.

Another feature from the findings that worth reporting here, was the high use of evidential, representing the textual dimension. Evidential was used consistently by all participants across the four areas of study in education. This consistent usage of evidential reflects the critical importance of establishing their academic credentials, in academic writing (Hyland \& Tse, 2004; Kuhi \& Behnam, 2011), and in constructing a 'skilled writer identity' (Hyland, 2004, pp.142). While the findings show that, the use of evidential by all participants is consistent. However, the frequency variations are different from drafts from educational management, planning, and policy, the highest (68\%) and language and literacy education, the lowest (23\%). It is important to stress that, the frequency variations found in this study do not suggest that, the field is different nor the academic practice, but, it is more of how the participants as writers choose to position themselves, and in constructing their academic credentials that appeal to their chosen fields of research.

On the other hand, the usage of transitions from the textual dimension found in the drafts is also relatively high compared to all the other categories of metadiscourse resources. In fact, it is the secondhighest (18\%), followed by evidential (46\%). Transition is a key way for writers to address the topic and demonstrate their reasoning in writing (Hyland \& Tse, 2004). This trait is important in academic writing because it helps writers to rethink their arguments and navigate their directions in choosing the best position to represent themselves in writing. It has also been found that high usage of evidential and transitions reflect unique qualities, in terms of the target audience and institutional roles (Kuhi \& Behnam, 2011). These two qualities could be explained in this study from two perspectives.

Table 3

Frequency of Textual, Engagement and Evaluative Dimensions of Academic Discourse (Educational Management, Planning, and Policy - EMPP)

\begin{tabular}{|c|c|c|c|c|c|c|c|c|c|c|c|}
\hline Dimension & & & Textual & & & & Engageme & & & Evaluative & \\
\hline Category & Transition & Evidentials & $\begin{array}{c}\text { Code } \\
\text { glosses }\end{array}$ & $\begin{array}{c}\text { Frame } \\
\text { markers }\end{array}$ & Endophorics & $\begin{array}{l}\text { Writer- } \\
\text { oriented } \\
\text { markers }\end{array}$ & $\begin{array}{l}\text { Reader- } \\
\text { oriented } \\
\text { markers }\end{array}$ & $\begin{array}{l}\text { Writer- } \\
\text { reader } \\
\text { oriented } \\
\text { markers }\end{array}$ & Hedges & Boosters & $\begin{array}{l}\text { Attitude } \\
\text { markers }\end{array}$ \\
\hline$\overline{\text { Counts }}$ & 257 & 676 & 87 & 91 & 127 & 42 & 14 & 11 & 176 & 49 & 10 \\
\hline $\begin{array}{l}\text { No. of } \\
\text { sentences }\end{array}$ & 1000 & 1000 & 1000 & 1000 & 1000 & 1000 & 1000 & 1000 & 1000 & 1000 & 1000 \\
\hline $\begin{array}{l}\text { Average } \\
\text { density }\end{array}$ & 0.26 & 0.68 & 0.09 & 0.09 & 0.13 & 0.04 & 0.01 & 0.01 & 0.18 & 0.05 & 0.01 \\
\hline
\end{tabular}

density

Total for Textual $=1238$ (average density $=0.25)$

Total for Evaluative $=235$ (average density $=0.08)$ 
Table 4

Frequency of Textual, Engagement and Evaluative Dimensions of Academic Discourse (Curriculum and Instructional Technology - CIT)

\begin{tabular}{|c|c|c|c|c|c|c|c|c|c|c|c|}
\hline Dimension & & & Textual & & & & Engageme & & & Evaluative & \\
\hline Category & Transition & Evidentials & $\begin{array}{c}\text { Code } \\
\text { glosses }\end{array}$ & $\begin{array}{c}\text { Frame } \\
\text { markers }\end{array}$ & Endophorics & $\begin{array}{l}\text { Writer- } \\
\text { oriented } \\
\text { markers }\end{array}$ & $\begin{array}{l}\text { Reader- } \\
\text { oriented } \\
\text { markers }\end{array}$ & $\begin{array}{l}\text { Writer- } \\
\text { reader } \\
\text { oriented } \\
\text { markers }\end{array}$ & Hedges & Boosters & $\begin{array}{l}\text { Attitude } \\
\text { markers }\end{array}$ \\
\hline Counts & 201 & 656 & 65 & 79 & 109 & 38 & 9 & 10 & 166 & 63 & 11 \\
\hline $\begin{array}{l}\text { No. of } \\
\text { sentences }\end{array}$ & 1256 & 1256 & 1256 & 1256 & 1256 & 1256 & 1256 & 1256 & 1256 & 1256 & 1256 \\
\hline $\begin{array}{l}\text { Average } \\
\text { density }\end{array}$ & 0.16 & 0.52 & 0.05 & 0.06 & 0.09 & 0.03 & 0.01 & 0.01 & 0.13 & 0.05 & 0.01 \\
\hline
\end{tabular}

Total for Textual $=1110($ average density $=0.18)$

Total for Evaluative $=240($ average density $=0.06)$

Total for Engagement $=57($ average density $=0.02)$;

Table 5

Frequency of Textual, Engagement and Evaluative Dimensions of Academic Discourse (Educational Psychology and Counseling - EPC)

\begin{tabular}{|c|c|c|c|c|c|c|c|c|c|c|c|}
\hline \multirow{2}{*}{$\begin{array}{l}\text { Dimension } \\
\text { Category }\end{array}$} & \multicolumn{5}{|c|}{ Textual } & \multicolumn{3}{|c|}{ Engagement } & \multicolumn{3}{|c|}{ Evaluative } \\
\hline & Transition & Evidentials & $\begin{array}{c}\text { Code } \\
\text { glosses }\end{array}$ & $\begin{array}{c}\text { Frame } \\
\text { markers }\end{array}$ & Endophorics & $\begin{array}{l}\text { Writer- } \\
\text { oriented } \\
\text { markers }\end{array}$ & $\begin{array}{l}\text { Reader- } \\
\text { oriented } \\
\text { markers }\end{array}$ & $\begin{array}{c}\text { Writer- } \\
\text { reader } \\
\text { oriented } \\
\text { markers }\end{array}$ & Hedges & Boosters & $\begin{array}{l}\text { Attitude } \\
\text { markers }\end{array}$ \\
\hline$\overline{\text { Counts }}$ & 227 & 696 & 99 & 93 & 137 & 0 & 0 & 0 & 17 & 10 & 8 \\
\hline $\begin{array}{l}\text { No. of } \\
\text { sentences }\end{array}$ & 1368 & 1368 & 1368 & 1368 & 1368 & 1368 & 1368 & 1368 & 1368 & 1368 & 1368 \\
\hline $\begin{array}{l}\text { Average } \\
\text { density }\end{array}$ & 0.17 & 0.51 & 0.07 & 0.07 & 0.10 & 0.00 & 0.00 & 0.00 & 0.01 & 0.01 & 0.01 \\
\hline
\end{tabular}

Total for Textual $=1252($ average density $=0.18)$

Total for Evaluative $=35$ (average density $=0.01)$

Total for Engagement $=0$ (average density $=0.00)$;

Table 6

Frequency of Textual, Engagement and Evaluative Dimensions of Academic Discourse (Language \& Literacy Education - LALE)

\begin{tabular}{|c|c|c|c|c|c|c|c|c|c|c|c|}
\hline Dimension & & & Textual & & & & Engageme & & & Evaluative & \\
\hline Category & Transition & Evidentials & $\begin{array}{c}\text { Code } \\
\text { glosses }\end{array}$ & $\begin{array}{c}\text { Frame } \\
\text { markers }\end{array}$ & Endophorics & $\begin{array}{l}\text { Writer- } \\
\text { oriented } \\
\text { markers }\end{array}$ & $\begin{array}{l}\text { Reader- } \\
\text { oriented } \\
\text { markers }\end{array}$ & $\begin{array}{l}\text { Writer- } \\
\text { reader } \\
\text { oriented } \\
\text { markers }\end{array}$ & Hedges & Boosters & $\begin{array}{l}\text { Attitude } \\
\text { markers }\end{array}$ \\
\hline$\overline{\text { Counts }}$ & 223 & 298 & 84 & 71 & 49 & 0 & 24 & 8 & 16 & 36 & 9 \\
\hline $\begin{array}{l}\text { No. of } \\
\text { sentences }\end{array}$ & 1296 & 1296 & 1296 & 1296 & 1296 & 1296 & 1296 & 1296 & 1296 & 1296 & 1256 \\
\hline $\begin{array}{l}\text { Average } \\
\text { density }\end{array}$ & 0.17 & 0.23 & 0.06 & 0.05 & 0.04 & 0.00 & 0.02 & 0.01 & 0.01 & 0.03 & 0.01 \\
\hline
\end{tabular}

Total for Textual $=725$ (average density $=0.11$ )

Total for Evaluative $=61($ average density $=0.02)$

Second, these doctoral students' drafts are written mainly for doctoral programs and higher education. Therefore, these writers may not use nonacademic language and employ features of academic writing. However, it is important to highlight that, as much as the institutional role may display complex qualities in how these writers should write academically, it does not foreground the idea that they can employ disciplinary metadiscourse effectively in writing. Also, they may not be aware of its function or practice of textual, engagement, and the evaluative dimension of academic discourse in the writing process. Moreover, their usage of disciplinary metadiscourse in academic writing could be contributed by their writing experiences and practices, and disciplinary knowledge. In a broad sense, these writers themselves might serve as their resources in how they use disciplinary metadiscourse to draft their doctoral research proposals.

Next, the engagement dimension was found to be the lowest $(3.1 \%)$ of all three dimensions. This low use of engagement dimension generally reflects the participants' uncertainties, in terms of engagement with self as writers. These participants are likely facing challenges with information processing and in unfolding their interpretations while drafting their research proposals. This finding also lends support to other studies with the view that writers in the university are less experience in employing engagement metadiscourse resources in academic writing (see Ho \& Li, 2018; Lee \& Deakin, 2016). However, it is important to highlight the distinction between these previous studies and the current study, which is a different group of writers. The previous 
studies involved undergraduates, while the current study focuses on first-year doctoral students. In this case, undergraduates may be less invested to enter the academic community, promote themselves as academic writers, or to engage with self as writers, during the writing process. First-year doctoral students, on the other hand, could have been more interested, than the undergraduates to announce their presence and construct their identity as academic writers, particularly, those who are looking forward to a career in academia. While these may delineate the differences between these two groups of writers, the first-year doctoral students raised the issue of disciplinary knowledge and familiarity with disciplinary metadiscourse which they might not develop yet, and their experiences in academic writing may be insufficient for them to represent themselves explicitly in academic writing. This may help to explain the underuse of engagement dimensions between these two groups of writers.

The findings in this study also confirm that the metadiscoursal occurrence for the evaluative dimension of academic discourse varies in the drafts across four areas of study in education. In particular, drafts from the curriculum and instructional technology (CIT) (average density: 0.06), and educational management, planning, and policy (EMPP) (average density: 0.05) employed more evaluative dimension of academic discourse in writing, compared to the other areas of study in education (see Table 3 and 4). The high usage of the evaluative dimension may be due to the fact that students in the EMPP areas of study are required to evaluate policy, while CIT students are required to perform curriculum evaluation. For such reasons, hedges, boosters, and attitude markers in the evaluative dimension of academic discourse play a more visible role in CIT and EMPP field of study, as these writers are expected to negotiate shifting certainties, opinions, and claims (Hyland, 2004). Given this, it is evident that the frequency of the evaluative dimension differs across areas of study, but it has to be noted that, the different areas of study do not cause metadiscoursal occurrences. Instead, it is more about the way students engage with their chosen fields of research that is different.

\section{CONCLUSION}

From the findings, it could be concluded that written discourse is formal in nature and foster minimal direct communication and interaction between the writer and the reader. The findings also revealed that textual realizations of interpersonal and rhetorical elements are critical in shaping the discourse of the academy, and in ensuring successful academic writing (Hyland, 2014; Hyland \& Jiang, 2018). It is for this reason that, awareness and understanding of disciplinary metadiscourse frame by the use of textual, engagement, and evaluative dimensions of academic discourse are important in academic writing. In terms of types, frequency, and patterns of using textual, engagement, and evaluative dimensions by first-year ESL doctoral students across four areas of study in the field of education, are almost similar. The frequency (from most to least used) for textual dimension: EPC - EMPP - CIT LALE; engagement dimension: EMPP - CIT LALE - EPC, and evaluative dimension: CIT EMPP - LALE - EPC. Indeed, these differences have important implications for understanding the process of academic writing particularly, in response to the writers' evaluation of their written works, how changes of disciplinary metadiscourse usage take place, and factors that might affect their rhetorical decisions and textual realization. It is also interesting to stress that, writers' usage of these three dimensions of metadiscourse can be influenced, by the field of study they engage in to carry out the different communicative functions in academic writing. However, it should be emphasized that this does not propose that, the field practice is different, but it is more of how the participants use the three dimensions: textual, engagement, and evaluative to engage in their chosen fields of research.

There is another important point to consider, this study has shown that the frequency of all three dimensions of academic discourse differs from all participants, during their first year of doctoral studies. More importantly, it shows change and development in terms of metadiscourse usage. For example, the frequency of textual, engagement, and evaluative dimensions of academic discourse across four areas of study in education changes across time. These changes occur from first written drafts to the final written drafts. These are first-year ESL doctoral students, who are writing in different fields of research. Here, it is clear that the different contexts, social meaning, and doctoral students' varied literacy practices, may have contributed to how the drafts were written to have different metadiscoursal occurrences. However, this change can also be due to the doctoral students' desire as writers to establish their academic credentials and position themselves within the academic community (Hyland, 2004). While it is true that, rhetorical decisions and textual realization depend on the ways writers negotiate their meaning in written texts is closely link to their chosen disciplines, further studies should look at how this usage of disciplinary metadiscourse changes and affects the development of writing overtime is needed.

This study relating to first-year ESL doctoral students' use of disciplinary metadiscourse, as well as, their development or changes in writing over time that has offers new insights, on how the three dimensions of metadiscourse shape the writers' propositions, and on the construction of writer's identity over time. Though these aspects were not explored in detail in this article, the findings of the 
study were in line with the metadiscourse concern, which points to the role of 'unpacking the decisions that writers make in creating a discourse by itself' (Hyland, 2004, pp. 140). This study is situated in doctoral students' drafts of the research proposal, for one year during their doctoral studies, instead of edited works that have been published. As such, the ideas presented here have the potential to be explored further and this may also support our teaching and learning of writing in university. This is, useful ways of assisting doctoral students, towards practices of disciplinary academic writing, and in constructing their writers' identity.

In conclusion, this research addressed specific questions about how first-year ESL doctoral students in the field of education employ textual, engagement, and evaluative dimensions of academic discourse, while writing their first year of doctoral studies. As noted by Hyland and Tse (2004), successful writing requires writers to perform communicative functions in texts. Such a notion asserts that the more writers are aware of the disciplinary metadiscourse functions, and understand its usage, the better the writers can present their arguments and achieve effective communication in academic writing. It is for this reason, disciplinary metadiscourse remains an indispensable model for the teaching and learning of academic writing and English for Specific Purposes (ESP) in university (Bhatia, 2014; Coffin, Curry, Goodman, Hewings, Lillis \& Swann, 2005; Evans \& Green, 2007; Hyland, 1999, 2014; Hyland \& Tse, 2004; Hyland \& Jiang, 2018). As such, this study has practical and pedagogical implications for the teaching and learning of disciplinary metadiscourse, with a focus on explicit explanation, demonstration, and practice of its usage and development in the academic writing process.

\section{ACKNOWLEDGEMENTS}

The authors would like to express their sincere gratitude to the reviewers for their comments on the earlier version of this article.

\section{FUNDING}

This work was conducted with the financial support (UM. TNC2/IPPP/81/10/1) provided by the Institute of Research Management \& Monitoring, University of Malaya.

\section{REFERENCES}

Adel, A. (2006). Metadiscourse in L1 and L2 English. John Benjamins Publishing Company.

Aitchison, C., \& Lee, A. (2006). Research writing: Problems and pedagogies. Teaching in Higher Education, 11(3), 265-278. https://doi.org/10.1080/13562510600680574

Anthony, L. (2014). AntConc (Version 3.4.4) [Computer Software]. Tokyo, Japan: Waseda
University. Available from http://www.laurenceanthony.net/

Bieber, J. P., \& Worley, L. K. (2006).

Conceptualizing the academic life: Graduate students' perspectives. The Journal of Higher Education, 77(6), 1009-1035. https://doi.org/10.1080/00221546.2006.117789 54

Breivega, R. K., Dahl, T., \& Flottum, K. (2002). Traces of self and others in research articles: A comparative pilot study of English, French and Norwegian research articles in medicine, economics, and linguistics. International Journal of Applied Linguistics, 12(2), 218-239. https://doi.org/10.1111/1473-4192.00032

Bhatia, V. K. (2014). A generic view of academic discourse. In J. Flowerdew (Ed.), Academic discourse (pp. 31-49). Routledge.

Cimasko, T., \& Reichelt, M. (2011). Foreign language writing instruction: Principles and practices. Parlor Press.

Coffin, C., Curry, M. J., Goodman, S., Hewings, A., Lillis, T., \& Swann, J. (2005). Teaching academic writing: A toolkit for higher education. Routledge.

Crismore, A. (1983). Metadiscourse: What is it and how is it used in school and non-school social science texts. University of Illinois.

Crismore, A. (1989). Talking with readers: Metadiscourse as rhetorical act. Peter Lang.

Crismore, A., \& Farnsworth, R. (1990). Metadiscourse in popular and professional science discourse. In W. Nash (Ed.), The writing scholar: Studies in academic discourse (118-136). Sage.

Dobakhti, L., \& Hassan, N. (2017). A corpus-based study of writer identity in qualitative and quantitative research articles. 3L: Language, Linguistics, Literature, 23(1), 1-14. https://doi.org/10.17576/3L-2017-2301-01

Evans, S., \& Green, C. (2007). Why ESP is necessary: A survey of Hong Kong tertiary students. Journal of English for Academic Purposes, 6(1), 3-17. https://doi.org/10.1016/j.jeap.2006.11.005

Halliday, M. A. K. (1994). An introduction to functional grammar (2nd ed.). Edward Arnold.

Harris, Z. S. (1959). The transformational model of language structure. Anthropological Linguistics, 1(1), 27-29.

Harwood, N. (2005). 'We do not seem to have a theory... The theory I present here attempts to fill this gap': Inclusive and exclusive pronouns in academic writing. Applied Linguistics, 26(3), 343-375. https://doi.org/10.1093/applin/ami012

Hewings, A., \& Hewings, M. (2001). Anticipatory "it" in academic writing: An indicator of disciplinary difference and developing disciplinary knowledge. In M. Hewings (Ed.), 
Academic writing in context (pp. 199-214).

University of Birmingham Press.

Ho, V., \& Li, C. (2018). The use of metadiscourse and persuasion: An analysis of first year university students' timed argumentative essays. Journal of English for Academic Purposes, 33, 53-68. https://doi.org/10.1016/j.jeap.2018.02.001

Hyland, K. (1998). Boosting, hedging, and the negotiation of academic knowledge. TEXT, 18(3), 349-382. https://doi.org/10.1515/text.1.1998.18.3.349

Hyland, K. (1999). Talking to students: Metadiscourse in introductory course books. English for Specific Purposes, 18(1), 3-26. https://doi.org/10.1016/S0889-4906(97)000252

Hyland, K. (2000). Hedges, boosters, and lexical invisibility: Noticing modifiers in academic texts. Language Awareness, 9(4), 179-197. https://doi.org/10.1080/09658410008667145

Hyland, K. (2002). Authority and invisibility: Authorial identity in academic writing. Journal of Pragmatics, 34(8), 1091-1112. https://doi.org/10.1016/S0378-2166(02)000358

Hyland, K. (2004). Disciplinary interactions: Metadiscourse in L2 postgraduate writing. Journal of Second Language Writing, 13(2), 133-151. https://doi.org/10.1016/j.jslw.2004.02.001

Hyland, K. (2005). Metadiscourse: Exploring Interaction in Writing. Continuum.

Hyland, K. (2008). As can be seen: Lexical bundles and disciplinary variation. English for Specific Purposes, 27(1), 4-21. https://doi.org/10.1016/j.esp.2007.06.001

Hyland, K. (2011). Looking through corpora into writing practices. In V. Vander, S. Zyingier, \& G. Barnbrook (Eds.) Perspectives on Corpus Linguistics. Studies in Corpus Linguistics (pp. 99-114). John Benjamins Publishing Company.

Hyland, K. (2012). Disciplinary identities: Individuality and community in academic discourse. Cambridge University Press.

Hyland, K. (2014). English for academic purposes. In C. Leung \& B. Street (Eds.), The Routledge companion to English studies. Routledge.

Hyland, K. (2015). Teaching and researching writing. Routledge.

Hyland, K. (2017). Metadiscourse: What is it and where is it going? Journal of Pragmatics, 113, 16-29. https://doi.org/10.1016/j.pragma.2017.03.007

Hyland, K., \& Jiang, F. K. (2018). "In this paper we suggest": Changing patterns of disciplinary metadiscourse. English for Specific Purposes, 51, 18-30.

https://doi.org/10.1016/j.esp.2018.02.001
Hyland, K., \& Tse, P. (2004). Metadiscourse in academic writing: A reappraisal. Applied Linguistics, 25(2), 156-177. https://doi.org/10.1093/applin/25.2.156

Jakobson, R. (1980). The framework of language. University of Michigan Press.

Jones, J. F. (2011). Using metadiscourse to improve coherence in academic writing. Language Education in Asia, 2(1), 1-14. https://doi.org/10.5746/LEIA/11/V2/I1/A01/JF JONES

Juliaty, H. (2019). Exploring academic identities of EFL novice writers. Indonesian Journal of Applied Linguistics, 9, 324-334. https://doi.org/10.17509/ijal.v9i2.20230

Kamler, B., \& Thomson, P. (2014). Helping doctoral students write: Pedagogies for supervision. Routledge.

Kuhi, D., \& Behnam, B. (2011). Generic variations and metadiscourse use in the writing of applied linguistics: A comparative study and preliminary framework. Written Communication, 28(1), 97-141. https://doi.org/10.1177/0741088310387259

Lautamatti, L. (1987). Observations on the development of the topic of simplified discourse. In U. Connor \& R. B. Kaplan (Eds.), Writing across languages (pp. 87-114). Addison-Wesley.

Lee, J. J., \& Deakin, L. (2016). Interactions in L1 and L2 undergraduate student writing: Interactional metadiscourse in successful and less successful argumentative essays. Journal of Second Language Writing, 33, 21-34. https://doi.org/10.1016/j.jslw.2016.06.004

Li, T., \& Wharton, S. (2012). Metadiscourse repertoire of L1 Mandarin undergraduate writing in English: A cross-contextual, crossdisciplinary study. Journal of English for Academic Purposes, 11(4), 345-356. https://doi.org/10.1016/j.jeap.2012.07.004

Matsuda, P. K., \& Tardy, C. M. (2007). Voice in academic writing: The rhetorical construction of author identity in blind manuscript review. English for Specific Purposes, 26(2), 235-249. https://doi.org/10.1016/j.esp.2006.10.001

Matsuda, P. K., Saenkhum, T., \& Accardi, S. (2013). Writing teachers' perceptions of thepresence and needs of second language writers: An institutional case study. Journal of Second Language Writing, 22(1), 68-86. https://doi.org/10.1016/j.jslw.2012.10.001

Park, G. (2013). 'Writing is a way of knowing': Writing and identity. ELT Journal, 67(3), 336345. https://doi.org/10.1093/elt/cct012

Swales, J. M. (1990). Discourse analysis in professional contexts. Annual Review of Applied Linguistics, 11, 103-114. https://doi.org/10.1017/S0267190500001987 
Swales, J. M. (2004). Research genres: Exploration and applications. Cambridge University Press. Thompson, G. (2001). Interaction in academic writing: Learning to argue with the reader. Applied Linguistics, 22(1), 58-78. https://doi.org/10.1093/applin/22.1.58

Vande Kopple, W. J. (1985). Some exploratory
Vold, E. T. (2006). Epistemic modality markers in research articles: A cross-linguistic and crossdisciplinary study. International Journal of Applied Linguistics, 16(1), 61-87. https://doi.org/10.1111/j.14734192.2006.00106.x

Williams, J. (1981). Style: Ten lessons in clarity and grace (3rd ed.). Scott Foresman.

discourse on metadiscourse. College

Composition and Communication, 26, 82-93.

https://eric.ed.gov/?id=EJ311449 


\begin{tabular}{|c|c|c|c|c|}
\hline $\begin{array}{l}\text { Dimension of } \\
\text { academic } \\
\text { discourse }\end{array}$ & $\begin{array}{l}\text { Educational management, } \\
\text { planning and policy }\end{array}$ & $\begin{array}{l}\text { Curriculum and instructional } \\
\text { technology }\end{array}$ & $\begin{array}{l}\text { Educational psychology } \\
\text { and counseling }\end{array}$ & Language and literacy education \\
\hline \multicolumn{5}{|l|}{ Textual } \\
\hline Transitions & $\begin{array}{l}\text { Additionally; also; } \\
\text { although; addition; } \\
\text { because; but; and; in; } \\
\text { despite; thus; moreover; } \\
\text { however; } \\
\text { furthermore; as a result; the } \\
\text { result is }\end{array}$ & $\begin{array}{l}\text { Additionally; also; } \\
\text { although; addition; } \\
\text { because; but; and; in; } \\
\text { despite; thus; moreover; } \\
\text { however; } \\
\text { furthermore; in contrast }\end{array}$ & $\begin{array}{l}\text { Additionally; also; } \\
\text { although; addition; } \\
\text { because; but; and; in; } \\
\text { despite; thus; though; } \\
\text { furthermore; in contrast; } \\
\text { therefore }\end{array}$ & $\begin{array}{l}\text { In addition; and; in; however; } \\
\text { although; } \\
\text { also; moreover; thus; but; in } \\
\text { contrast; on the other hand; } \\
\text { while; therefore; whereas; } \\
\text { furthermore; yet }\end{array}$ \\
\hline Frame markers & $\begin{array}{l}\text { Third; to; summarize; finally; } \\
\text { back to; would like to; to } \\
\text { start with; in conclusion }\end{array}$ & $\begin{array}{l}\text { The purpose of this study is } \\
\text { to examine; first, } \\
\text { consequently; in other } \\
\text { words; to start with; in } \\
\text { conclusion }\end{array}$ & $\begin{array}{l}\text { Finally, the aim of this } \\
\text { study; to summarize, } \\
\text { first; in short; in } \\
\text { conclusion; to sum up }\end{array}$ & $\begin{array}{l}\text { The aim of the present study; the } \\
\text { purpose of this study, first; } \\
\text { second; in this study; will be } \\
\text { discussed; finally; in conclusion }\end{array}$ \\
\hline $\begin{array}{l}\text { Endophoric } \\
\text { markers }\end{array}$ & $\begin{array}{l}\text { Similarly; Table } 1 \text { refer to; } \\
\text { see Figure 1; the result; the } \\
\text { finding; following; as seen } \\
\text { above; below; mentioned } \\
\text { above }\end{array}$ & $\begin{array}{l}\text { See Figure 1, See Table } 1 \text {, } \\
\text { These results; given; } \\
\text { following; mentioned above }\end{array}$ & $\begin{array}{l}\text { Similarly; this type; } \\
\text { these problems; these } \\
\text { questions; see Figure } 1 ; \\
\text { see Table } 1 \text {; these } \\
\text { results; this view }\end{array}$ & $\begin{array}{l}\text { Similarly; likewise; similar vein; } \\
\text { see Figure 1, see Table 1; noted } \\
\text { above; shown below; this } \\
\text { perspective; this view; the results } \\
\text { are given; these findings }\end{array}$ \\
\hline Evidentials & $\begin{array}{l}\text { According to Krik (2010); } \\
\text { And and Van Dyne (2008) } \\
\text { stated that; }\end{array}$ & $\begin{array}{l}\text { Fullen and Stiegelbauer } \\
\text { (1991) suggested; Hall and } \\
\text { Hord (2011) noted; Conroy } \\
\text { (1999) state; Haugen (2008) } \\
\text { reported that }\end{array}$ & $\begin{array}{l}\text { According to Bandura } \\
\text { (1977); Bong and Clark } \\
\text { (1999) noted that; } \\
\text { Cubillos and Ilvento } \\
\text { (2013) found that; As } \\
\text { noted by Wigfield and } \\
\text { Guthrie (1997); Hill } \\
\text { (1981) state }\end{array}$ & $\begin{array}{l}\text { According to Popham (2013); } \\
\text { DeLuca and Klinger (2010) } \\
\text { view; Mertler (2009) noted }\end{array}$ \\
\hline Code glosses & $\begin{array}{l}\text { Such as; meaning; for } \\
\text { example; for instance; namely }\end{array}$ & $\begin{array}{l}\text { Such as; for example; } \\
\text { namely; this means }\end{array}$ & $\begin{array}{l}\text { Such as, namely; for } \\
\text { example; this means; } \\
\text { which means; to simplify } \\
\text { it; previously }\end{array}$ & $\begin{array}{l}\text { For example, such as; e.g.; the } \\
\text { following questions }\end{array}$ \\
\hline \multicolumn{5}{|l|}{ Engagement } \\
\hline $\begin{array}{l}\text { Writer-oriented } \\
\text { markers }\end{array}$ & I; we; my & I' we; my; our & - & - \\
\hline $\begin{array}{l}\text { Reader-oriented } \\
\text { markers }\end{array}$ & You & You & - & You \\
\hline $\begin{array}{l}\text { Writer-reader } \\
\text { oriented markers }\end{array}$ & As you can see; we & $\begin{array}{l}\text { We; you may assume; } \\
\text { we think it is }\end{array}$ & - & Our; as we all are aware; we \\
\hline \multicolumn{5}{|l|}{ Evaluative } \\
\hline Hedges & $\begin{array}{l}\text { Perhaps; would; less likely; } \\
\text { could; can; appears to; may; } \\
\text { perhaps; suggest }\end{array}$ & $\begin{array}{l}\text { Might; perhaps; can; could; } \\
\text { should }\end{array}$ & $\begin{array}{l}\text { Could; can; appear to; } \\
\text { somewhat; suggest; } \\
\text { possible; doubt; should; } \\
\text { speculate; suspect; } \\
\text { somewhat; according to } \\
\text { my knowledge; } \\
\text { apparently; appear; } \\
\text { claimed; concern; } \\
\text { relatively }\end{array}$ & $\begin{array}{l}\text { Could; can; might; would; } \\
\text { perhaps; maybe; most likely; less } \\
\text { likely, possible; suggest; seems; } \\
\text { indicate }\end{array}$ \\
\hline Boosters & $\begin{array}{l}\text { Significantly; it is apparent } \\
\text { that; there is no doubt that; } \\
\text { certainly; in fact; must; } \\
\text { definitely }\end{array}$ & $\begin{array}{l}\text { Significantly; it is clear that; } \\
\text { it was particularly important; } \\
\text { definitely; think it is; in fact }\end{array}$ & $\begin{array}{l}\text { There is no doubt; must } \\
\text { think; in fact; especially; } \\
\text { evident; obvious; } \\
\text { showed; maybe; in my } \\
\text { opinion; true; really; } \\
\text { shows; shown above; the } \\
\text { fact is }\end{array}$ & $\begin{array}{l}\text { It is apparent that; It seems like; } \\
\text { noteworthy; it was critical; it was } \\
\text { important }\end{array}$ \\
\hline Attitude markers & $\begin{array}{l}\text { Surprisingly; unfortunately; } \\
\text { important; should; it would } \\
\text { seem like; unusual; } \\
\text { necessary; more importantly; } \\
\text { support; of importance }\end{array}$ & $\begin{array}{l}\text { Unfortunately; interestingly; } \\
\text { important; support; }\end{array}$ & $\begin{array}{l}\text { Surprisingly; I beg to } \\
\text { differ; important; } \\
\text { strongly; effectively; it } \\
\text { may suggest that; it } \\
\text { seems possible to infer } \\
\text { that; supported; crucial; } \\
\text { importantly; } \\
\text { understandable }\end{array}$ & $\begin{array}{l}\text { I agree; it is interesting; } \\
\text { important; effectively }\end{array}$ \\
\hline
\end{tabular}

